УДК 159.9

https://doi.org/10.52058/2708-7530-2021-11(17)-218-230

Халявка Юлія Григорівна головний судовий експерт відділу досліджень у сфері інформаційних технологій, Черкаський науково-дослідний експертно-криміналістичний центр Міністерства внутрішніх справ України, вул. Пастерівська, 104, м. Черкасси, 18000, тел.: (067) 855-05-62, e-mail: zajka0711@ukr.net, https://orcid.org/0000-0002-8848-2512

Тульвінська Анна Юріївна судовий експерт відділу досліджень у сфері інформаційних технологій, Черкаський науково-дослідний експертнокриміналістичний центр Міністерства внутрішніх справ України, вул. Пастерівська, 104, м. Черкасси, 18000, тел.: (063) 452-54-63, e-mail: anetk@ukr.net, https://orcid.org/0000-0002-2801-1612

\title{
ПРАВОВИЙ СТАТУС СУДОВОГО ЕКСПЕРТА-ПСИХОЛОГА У СПРАВАХ ПРО ВІДШКОДУВАННЯ МОРАЛЬНОЇ ШКОДИ
}

Анотація. У статті розглянуто правовий статус експерта у справах про відшкодування моральної шкоди. Досліджено правове регулювання повноважень експерта, виявлено прогалини та недоліки в ньому. Для оптимізації використання спеціальних психологічних знань у судовій експертизі необхідне осмислення основних організаційно-правових, теоретичних і методологічних проблем, пов'язаних з професійною діяльністю судового експерта-психолога. Це має не тільки самостійне значення, але i служить надійною опорою при проведенні конкретних експертних досліджень, визначаючи в кожному предметному вигляді експертизи мету психологічного дослідження, методичні засоби їі досягнення, межі компетенції експерта, обсяг і зміст експертного висновку, грамотне формулювання експертних висновків. До правових елементів правового статусу судового експерта-психолога віднесено їхні юридичні обов'язки та права, заборонні заходи, коли експерту прямо забороняється вчиняти певні дії, та його юридичну відповідальність за неналежне виконання своїх посадових обов'язків, або зловживання ними. Внутрішнє переконання експерта є нічим іншим, як почуття впевненості у правильності прийнятого ним рішення. Принциповою особливістю тут є те, що примушувати експерта до прийняття будь-якого рішення не мають права ні керівник експертної установи, ні будь-хто інший, інакше ми спостерігаємо порушення принципу незалежності експерта, з одного боку, i порушення етичних правил - 3 іншого. Експерт робить висновки на основі аналізу результатів проведеного дослідження та згідно із законом несе повну відповідальність за свої висновки. Зроблено висновок, що для отримання повної компенсації моральної шкоди необхідно використовувати всі наявні 
процесуальні можливості, намагатися найбільш повно і точно відобразити причинно-наслідковий зв'язок між порушенням прав людини та моральними стражданнями, які вона зазнала. Не повинно бути сумнівів щодо розміру моральної шкоди, і це повинно бути підтверджено за допомогою прийнятних засобів доказування.

Ключові слова: судовий експерт, правовий статус експерта, висновок експерта, призначення та проведення експертизи.

Khaliavka Yuliia Chief forensic expert at department of IT research Cherkassy SRFC MMIA of Ukraine, Pasterivska St., 104, Cherkassy, 18000, tel.: (067) 855-05-62, e-mail: zajka0711@ukr.net, https://orcid.org/0000-0002-8848-2512

Tulvinska Anna Forensic expert at department of IT research Cherkassy SRFC MMIA of Ukraine, Pasterivska St., 104, Cherkassy, 18000, tel.: (063) 452-54-63, e-mail: anetk@ukr.net, https://orcid.org/0000-0002-2801-1612

\title{
LEGAL STATUS OF A FORENSIC EXPERT-PSYCHOLOGIST IN CASES OF COMPENSATION FOR MORAL DAMAGE
}

\begin{abstract}
The article considers the legal status of an expert in cases of compensation for non-pecuniary damage. The legal regulation of the expert's powers has been studied, gaps and shortcomings in it have been identified. To optimize the use of special psychological knowledge in forensic examination, it is necessary to understand the main organizational, legal, theoretical and methodological problems associated with the professional activities of forensic psychologists. This has not only independent significance, but also serves as a reliable support in conducting specific expert research, determining in each subject type of examination the purpose of psychological research, methodological means of achieving it, the limits of expert competence, scope and content of expert opinion, competent formulation of expert opinions. The legal elements of the legal status of a forensic psychologist include their legal responsibilities and rights, prohibitive measures when the expert is expressly prohibited from performing certain actions, and his legal responsibility for improper performance of his official duties, or abuse of them. The inner conviction of an expert is nothing but a sense of confidence in the correctness of his decision. A fundamental feature here is that neither the head of the expert institution nor anyone else has the right to force an expert to make any decision, otherwise we observe a violation of the principle of independence of the expert, on the one hand, and a violation of ethical rules on the other. The expert draws conclusions based on the analysis of the results of the study and in accordance with the law is fully responsible for their conclusions. It is concluded that in order to obtain full compensation for non-pecuniary damage, it is necessary to use all available procedural possibilities, to try to most fully and accurately reflect the causal link
\end{abstract}


between human rights violations and the moral suffering it has suffered. There must be no doubt as to the extent of the non-pecuniary damage, and this must be substantiated by acceptable means of proof.

Keywords: forensic expert, legal status of the expert, expert opinion, appointment and examination.

Постановка проблеми. Людина, ii життя, здоров’я, честь і гідність, недоторканність і безпека визнаються найвищою соціальною цінністю.

У сьогоденні кількість позовів, що містять потреби у відшкодуванні моральної (немайнової) шкоди у результаті неправомірних дій роботодавців, справ щодо захисту честі, гідності та ділової репутації, шкоди, заподіяної дорожньо-транспортною пригодою, незаконного засудження, триманням під вартою, спричинення смерті близького родича, спричинення шкоди здоров’ю, тощо неухильно зростає.

Сам факт наявності в особи моральних страждань може бути визначений за допомогою психологічного дослідження на етапі судового розгляду кримінального провадження. Однак, експертизи виконуються не в якісь безособовій формі, а конкретними спеціально підготовними та сертифікованими посадовими особами, експертами-психологами. Їх правовий статус під час досудового розслідування в судовому процесі $є$ недосконалим. В чинному законодавстві існує низка несумісностей та недоліків.

Аналіз останніх досліджень і публікацій. 3'ясуванню правового статусу експерта присвячено праці таких учених, як С. М. Абрамов, В. Д. Арсеньєв, Р. С. Бєлкін, В. Є. Бергер, С. С. Бичкова, Ж. В. Васильєва-Шаламова, В. Г. Гончаренко, В. Р. Ілейко, Т. М. Кучер, Р. Я. Лемик, В. І. Тертишніков, М. К. Треушніков, М. Й. Штефан, К. С. Юдельсон та ін. Проте на практиці виникає багато питань, пов'язаних із відсутністю теоретичних розробок окремих аспектів участі експерта у цивільному процесі, із прогалинами у правовому регулюванні, що й зумовлює необхідність розробки цих питань.

Мета статті - виявити i проаналізувати проблеми, що виникають у випадках залучення судового експерта на практиці.

Виклад основного матеріалу. Судова експертиза - це дослідження експертом на основі спеціальних знань матеріальних об'єктів, явищ і процесів, які містять інформацію про обставини справи, що перебуває у провадженні органів досудового розслідування чи суду [11]. Судово-психологічна експертиза (СПЕ) - одна 3 головних форм практичного застосування спеціальних психологічних знань у кримінальному чи цивільному процесі. Вона проводиться за постановою слідчого, ухвалою суду або клопотанням адвоката щодо осудних підслідних, свідків чи потерпілих. Загальним предметом СПЕ є дослідження психічної діяльності, особливості якої важливі для встановлення істини в судовому діловодстві. Експертом у кримінальному провадженні $є$ особа, яка володіє науковими, технічними або іншими спеціальними знаннями, має право відповідно 
до Закону України "Про судову експертизу" на проведення експертизи і якій доручено провести дослідження об'єктів, явищ і процесів, що містять відомості про обставини вчинення кримінального правопорушення, та дати висновок 3 питань, які виникають під час кримінального провадження і стосуються сфери іiі знань [7].

Участь експерта у кримінальному провадженні досить суттєво впливає на можливості сторін кримінального провадження при збиранні, перевірці та оцінці доказів 3 метою забезпечення швидкого, повного та неупередженого розслідування і судового розгляду. Висновок експерта, що наданий особою, яка $\epsilon$ не зацікавленою у результатах кримінального провадження, 3 посиланням на фундаментальні наукові положення та апробовані методики проведення дослідження, який, при необхідності, може бути перевірений, а також показання експерта $\epsilon$ процесуальними джерелами доказів. Психолог в ролі експерта несе велику моральну і правову відповідальність за істинність, науковість і об'єктивність проведеного ним дослідження, інтерпретацію отриманих даних і представлений висновок.

Відповідно до ст. 75 КПК України, експертиза призначається у тих випадках, коли для вирішення певних питань при провадженні в справі необхідні наукові, технічні або інші спеціальні знання. Під спеціальними знаннями в даному випадку слід вважати такі знання, якими професійно володіє вузьке коло спеціалістів і які не належать до загальновідомих та загальнодоступних. Іншими словами, предметом дослідження експерта можуть бути будь-які факти та обставини, з'ясування яких потребує поглиблених знань у тій чи іншій сфері науки, техніки, мистецтва або ремесла, досвіду практичної роботи, що відповідають сучасному науковому i практичному рівню [7].

Поняття «моральна шкода» досить впевнено ввійшло в судову практику, у зв’язку з чим усе більшого значення набуває інститут іiі компенсації, заподіяної злочином або іншим порушенням, які посягають на особисті немайнові права громадянина та інші належні йому нематеріальні блага. Це регламентується Конституцією України, Цивільним кодексом України та іншими нормативно-правовими актами ( у тому числі, постановою Пленуму Верховного Суду України від 31 березня 1995 р. №4 «Про судову практику у справах про відшкодування моральної (немайнової) шкоди»). Можливість відшкодування громадянам завданої моральної шкоди, безперечно, є одним із механізмів забезпечення прав людини, а судово-психологічна експертиза 3 питань визначення моральної шкоди в наш час стала важливим джерелом доказів у таких категоріях справ [1].

На думку В. Васильєва, законодавець утримується від визначення поняття «моральна (немайнова) шкода», оскільки таке визначення, щоб охопити всі суттєві ознаки поняття, було б доволі громіздким: усі випадки неправомірних дій, якими може бути заподіяна моральна (немайнова) шкода, неможливо 
передбачити, до того ж моральна (немайнова) шкода може бути завдана й іншими діями, якими порушуються майнові й особисті немайнові права особи [4, С. 12].

Слід згодитися 3 думкою I.В. Бурлаки, яка визначає, що відшкодування шкоди може розглядатися принаймні у двох площинах: по-перше, як спосіб захисту порушених цивільних прав та інтересів, по-друге - як міра цивільноправової відповідальності [3, С. 8]. 3 іншого міркування цілком закономірним видається загальний принцип вини, згідно з яким людина не може наділятися безеквівалентним майновим обтяженням, якщо тільки людина не є винуватою в заподіяній шкоді.

Необхідно підкреслити, що у вітчизняній літературі пропонувалися різні визначення поняття зобов'язань із відшкодування шкоди. Так Г.В. Єрьоменко формулювала їх як «такі цивільно-правові зобов'язання, в яких потерпіла сторона (кредитор) має право вимагати від боржника (заподіювача шкоди) повного відшкодування протиправного заподіяної шкоди шляхом надання відповідного майна в натурі або відшкодування збитків» [13, С. 322]. Подібне за сутністю, але дещо інше за формулюваннями визначення зобов'язань відшкодування шкоди було запропоноване С.Н. Приступною та C.С. Сиротенко, котрі визначали його як «зобов'язання, тобто правовідношення, яке виникає внаслідок протиправного завдання шкоди, у зв'язку 3 чим потерпіла сторона (кредитор) має право вимагати від правопорушника, який завдав шкоди (боржника), виконання його обов'язку відшкодувати завдану шкоду» [2, С. 478-479]. С.Д. Русу зазначає, що «за зобов'язаннями 3 відшкодування шкоди особа, яка завдала шкоди неправомірними рішеннями, діями чи бездіяльністю особистим немайновим правам фізичної чи юридичної особи, а також майну фізичної або юридичної особи, зобов'язана іiі відшкодувати, а потерпілий має право на відшкодування завданої шкоди в повному обсязі» [12, С. 373].

Аналіз думок учених щодо визначення поняття зобов'язання 3 відшкодування шкоди дає можливість зробити висновок, що підставами виникнення зобов'язань із відшкодування шкоди є такі: наявність шкоди в потерпілого; протиправна поведінка заподіювача шкоди; причинний зв'язок між протиправною поведінкою та шкодою; наявність вини особи, яка завдала шкоди.

Виходячи 3 указаного, юридичне поняття «моральна шкода» полягає у комплексі втрат немайнового характеру внаслідок моральних чи фізичних страждань, або інших негативних явищ, заподіяних фізичній чи юридичній особі незаконними діями або бездіяльністю інших осіб, містить певну форму вини заподіювача шкоди та наявність причинного зв'язку між неправомірним діянням та настанням моральної шкоди.

Тобто, необхідною та достатньою умовою виникнення негативних змін у життєдіяльності позивача (потерпілого) у вигляді моральних чи фізичних страждань має бути протиправна (неправомірна) дія чи бездіяльність 
заподіювача шкоди. Встановлення факту вини, правова кваліфікація неправомірності дій заподіювача шкоди є прерогативою суду.

Психологічним змістом моральних страждань є негативні зміни психічної діяльності особи. Для адаптації до таких змін суб’єкту необхідно затратити психічні ресурси, які в іншій ситуації він міг би витратити на інші корисні для себе цілі. Такі «суб’єктивні втрати» або несприятливі придбання і складають психологічний компонент моральних страждань. Експертами вивчається психічна діяльність особи, яка претендує на компенсацію моральної шкоди, в юридично значущий період, що включає ситуацію заподіяння моральної шкоди, а також ситуацію, що настала після правопорушення, пов'язану 3 моральними i фізичними стражданнями. Іноді досліджується ситуація соціальної взаємодії між особою, що заподіяла шкоду і потерпілою особою, між потерпілим і оточуючим його соціумом.

Найпоширенішими випадками, коли вирішується питання про відшкодування моральної (немайнової) шкоди є:

- поширення, у тім числі, через засоби масової інформації, відомостей, що не відповідають дійсності, або викладені неправдиво, порочать честь, гідність, ділову репутацію;

- відшкодування шкоди, завданої майну та здоров'ю (найчастіше, у зв'язку з дорожньо-транспортною пригодою, залиттям квартири);

- порушення прав споживачів;

- порушення законодавства про охорону навколишнього середовища;

- прийняття незаконних рішень, а також дії чи бездіяльність органу дізнання, судового слідства, прокуратури або суду;

- вчинення корупційного діяння;

- скоєння злочину;

- пошкодження майна;

- завдання шкоди джерелом підвищеної небезпеки.

Відповідно до Постанови Пленуму Верховного Суду України від 31 березня 1995 року № 4 «Про судову практику в справах про відшкодування моральної (немайнової) шкоди», зазначалося, що моральна шкода може полягати, зокрема, у приниженні честі, гідності, престижу або ділової репутації, моральних переживаннях у зв’язку з нанесенням шкоди здоров'ю, у порушенні права власності (в тому числі інтелектуальної), прав, наданих споживачам, інших цивільних прав, у зв’язку з незаконним перебуванням під слідством i судом, у порушенні нормальних життєвих зв'язків через неможливість продовження активного громадського життя, порушенні стосунків з оточуючими людьми, при настанні інших негативних наслідків. Крім того, пункт 9 цієї постанови вказує на те, що розмір відшкодування моральної (немайнової) шкоди суд визначає залежно від характеру та розміру страждань (фізичних, душевних, психічних тощо), яких зазнав позивач, характеру немайнових втрат (їх тривалості, можливості відновлення і тощо), а 
також 3 огляду на інші обставини. Зокрема, враховуються стан здоров’я потерпілого, тяжкість вимушених змін у його життєвих i виробничих стосунках, ступінь падіння престижу, ділової репутації, час та зусилля, необхідні для повернення до первісного стану [10].

Варто враховувати, що на практиці існують три варіанти визначення розміру компенсації моральної шкоди:

1. В переважній більшості випадків суд встановлює розмір самостійно (абз.2 ч.3 ст.23 ЦК - Розмір грошового відшкодування моральної шкоди визначається судом залежно від характеру правопорушення, глибини фізичних та душевних страждань, погіршення здібностей потерпілого або позбавлення його можливості їх реалізації, ступеня вини особи, яка завдала моральної шкоди, якщо вина $є$ підставою для відшкодування, а також $з$ урахуванням інших обставин, які мають істотне значення. При визначенні розміру відшкодування враховуються вимоги розумності і справедливості).

2. Береться за основу сума компенсації моральної шкоди, яку позивач самостійно вираховує, відкориговується та застосовуються принципи розумності і справедливості (ст.23 ЦК), проте у справах, де розмір позовних вимог був вирахуваний відповідно до методик, призначена судом компенсація $\epsilon$ вищою від тих, де такого вмотивування не було.

3. Орієнтовний розмір відшкодування моральної шкоди визначається відповідно до висновку судового експерта-психолога із застосуванням судово-психологічних методик, порядок призначення i проведення якої регулюється нормативно правовими актами України. Експерт, як правило, оцінює розмір моральної шкоди, рівній певній кількості мінімальних заробітних плат.

Основним видом неправомірної поведінки, що має значення у справах за позовом про відшкодування моральної шкоди, є правопорушення - тобто винна протиправна дія (бездіяльність). Ознаки правопорушення визначаються у складі правопорушення, тобто у сукупності закріплених у юридичних нормах його сторін та елементів. Правопорушення за характером суспільної шкоди (небезпеки) поділяються на злочини та проступки (адміністративні делікти, дисциплінарні проступки, цивільні правопорушення та ін.).

A.M. Ерделевський вказує, що «немає інструментів для точного вимірювання абсолютної глибини страждань людини, а також підстав для вираження глибини цих страждань у грошах. У коштах може бути виражена лише компенсація за перенесені страждання. Іншими словами, це своєрідний штраф, який i стягується 3 заподіювача шкоди на користь потерпілого i призначений для згладжування негативного впливу на психіку потерпілого у зв’язку iз завданням йому страждань. Оскільки глибина страждань не піддається точному виміру, а в грошах не вимірна в принципі, неможливо говорити про будь-яку еквівалентність глибини страждань розміру компенсації. Однак розумно і справедливо припустити, що більшій глибині 
страждань повинен відповідати більший розмір компенсації, і навпаки, що розмір компенсації повинен бути адекватним перенесеним стражданням» [5, С. 55-67]. Виплата майнової компенсації за немайнову шкоду завжди буде нести в собі елемент умовності через відсутність загальних «одиниць виміру» матеріальної і нематеріальної субстанцій.

Доведення факту завдання моральної шкоди є дуже специфічним, тому позивачу непросто сформувати необхідну доказову базу для підтвердження наявності моральної шкоди та підтвердження причинно-наслідкового зв'язку між діями (бездіяльністю) відповідача та негативними наслідками для позивача у вигляді моральної шкоди. У більшості позовів про компенсацію моральної (немайнової) шкоди, які надходять до судів, позивачі обмежуються фразою: «Мені завдано моральної шкоди». Однак позивачеві недостатньо заявити у позовній заяві, що він пережив або переживає моральні страждання. Цей факт має бути доведений усіма допустимими засобами доказування (показаннями свідків, довідками із медичних закладів, іншими письмовими доказами тощо) [8, С. 21]. Докази - це будь-які фактичні дані, на підставі яких суд встановлює наявність або відсутність обставин, що обгрунтовують вимоги і заперечення сторін, та інші обставини, що мають значення для правильного вирішення справи. Ці дані встановлюються такими засобами: поясненнями сторін, третіх осіб, їхніх представників, допитаних як свідків; показаннями свідків, письмовими доказами, речовими доказами, зокрема звуко- i відеозаписами, висновками експертів. Пояснення сторін і третіх осіб надаються сторонами в цивільному процесі й фіксуються у протоколі судового засідання, а в деяких випадках із застосуванням технічних засобів (у таблиці, що подається нижче, цей вид доказу не розглядатиметься). Сторони, треті особи та їхні представники за їхньою згодою можуть бути допитані як свідки про відомі їм обставини, що мають значення для справи. Показання свідків це повідомлення про відомі йому обставини, які мають значення для справи. Не $\epsilon$ доказом показання свідка, який не може назвати джерела своєї обізнаності щодо певної обставини. У справах про компенсацію моральної шкоди цей вид доказів є найбільш поширеним. Адже зміну психологічного стану позивача у зв'язку з негативними емоційно-вольовими переживаннями можуть помітити тільки особи, які мають можливість порівняти стан позивача до події, яка спричинила переживання, та після такої події. Зважаючи на те, що явка у судовий процес $\epsilon$ для громадян неабияким психологічним випробовуванням, позивач пропонує до виклику тих осіб, які вже надали йому теоретичну згоду на виклик їх у якості свідків. Однак дійсно корисними для з'ясування обсягів спричиненої моральної шкоди є показання «незалежних» свідків - осіб, які спостерігали за позивачем «збоку» (наприклад, колеги по роботі, з якими позивач не підтримує тісних дружніх стосунків), або осіб, які ставляться до позивача «вимушено терпляче» (як правило, це особи, які підтримують стосунки 3 позивачем в силу незалежних від них обставин 
(наприклад, родичі одного 3 подружжя). На жаль, суди здебільшого не вживають належних заходів для залучення таких свідків. Письмові докази - це будь-які документи, акти, довідки, листування службового або особистого характеру або витяги 3 них, що містять відомості про обставини, які мають значення для справи. Письмові докази у справах про компенсацію моральної шкоди, як правило, підтверджують наявність негативних наслідків, які виникли у зв'язку з перенесеними емоційно-вольовими переживаннями. Це може бути витяг з історії хвороби, лікарняний листок, письмовий висновок психолога тощо, але щодо того, у який час ці переживання мали місце, що стало їхньою причиною, до чого вони призвели, якої вони були глибини.

До компетенції судового експерта-психолога відповідно до Інструкції про призначення та проведення судових експертиз та експертних досліджень належать: установлення того факту, що ситуація, яка досліджується в справі, $\epsilon$ психотравмуючою для підекспертної особи; якщо так, то чи завдані особі страждання (моральна шкода); якщо особі завдано страждання (моральну шкоду), то який можливий розмір становить грошова компенсація за завданні страждання (моральну шкоду) [6]. До компетенції судового експерта при психологічному дослідженні у справах щодо заподіяння моральних страждань особі та відшкодування моральної шкоди відносяться встановлення психологічних факторів та механізмів, у результаті яких у потерпілої особи (позивача у справі) відбулися негативні зміни в індивідуально-психологічних проявах, в оптимальному психічному стані, у звичайній діяльності, соціальній адаптації, у соціальному функціонуванні як особистості. До компетенції судового експерта-психолога при психологічному дослідженні у справах щодо заподіяння моральних страждань особі та відшкодування моральної шкоди не відноситься вирішення питань етичного, філософського, медичного (у тому числі - психіатричного), правового характеру.

Не $\epsilon$ винятком й правовий статус експерта-психолога, як учасника процесуального провадження, адже він наділений процесуальним статусом, який формується 3 моменту його залучення у провадження. Для реалізації своєї діяльності у кримінальному провадженні, процесуальний закон наділяє експерта правами та обов'язками, які складають основу його процесуального статусу та відрізняють експерта від інших учасників провадження.

Слід зазначити, що експерт у своєму висновку не встановлює факт моральної шкоди ( це юридичний критерій), а встановлює моральні страждання особи та їх причинно-наслідковий зв'язок 3 діями/бездіяльністю відповідача, які в свою чергу можуть виступати підставою для кваліфікації судом факту заподіяння моральної шкоди.

Згідно із діючим законодавством експерт-психолог зобов'язаний: заявити самовідвід за наявності передбачених законодавством обставин; прийняти до виконання доручену йому експертизу; особисто провести повне дослідження, дати обгрунтований та об'єктивний письмовий висновок на поставлені питання, а в разі необхідності роз'яснити його. Експерт-психолог зобов'язаний 
провести дослідження безпосередньо, тобто повинен провести експертизу особисто, без залучення інших осіб.

Також, на нашу думку, невід’ємним чинником правового статусу судового експерта-психолога під час досудового розслідування та в судовому процесі $\epsilon$ його юридична відповідальність за неналежне виконання своїх посадових обов'язків, або зловживання ними. Відповідно ст. 14 Закону України «Про судову експертизу», судовий експерт на підставах і в порядку, передбаченими законодавством, може бути притягнутий до дисциплінарної, матеріальної, адміністративної чи кримінальної відповідальності. За надання завідомо неправдивого висновку, за відмову без поважних причин від виконання покладених на нього обов'язків, а також за розголошення даних, що стали йому відомі під час проведення експертизи, експерт несе кримінальну відповідальність згідно 3 чинним законодавством. Кримінальна відповідальність експерта за завідомо неправдивий висновок та за відмову експерта виконувати покладені на нього обов'язки є гарантією достовірності висновку експерта та належного виконання ним своїх професійних обов’язків. За злісне ухилення від явки до органів досудового розслідування або суду експерт несе адміністративну відповідальність згідно 3 чинним законодавством. За допущені порушення під час проведення експертизи, що не тягнуть за собою кримінальної чи адміністративної відповідальності, експерт може бути притягнутий до дисциплінарної відповідальності згідно з чинним законодавством. У разі завдання своїми діями майнової шкоди під час проведення експертизи експерт несе матеріальну відповідальність згідно 3 чинним законодавством [11].

Судовий експерт-психолог використовує конкретні методики, зареєстровані в Реєстрі методик проведення судових експертиз, та, відповідно до п. 14 Порядку ведення Реєстру методик проведення судових експертиз, у разі потреби під час проведення експертиз також можуть використовуватись науково-технічна та довідкова література, перелік якої затверджується наказом Міністерства юстиції України та не є вичерпним, інформаційні бази даних з мережі Інтернет, а також програмні продукти, рекомендовані для застосування в експертній практиці рішенням Координаційної ради з проблем судової експертизи при Міністерстві юстиції України [9].

Експерт-психолог має право застосовувати ті методи, методики, наукові джерела, які, з огляду на свої спеціальні знання, вважає необхідними для вирішення поставленого перед ним експертного завдання. Визначення способу проведення експертизи належить до компетенції експерта [6].

Професійна компетентність складається із спеціальних пізнань у галузі юридичної психології, мистецтва проведення психодіагностичного дослідження в процесі взаємодії 3 різними категоріями підекспертних; постійного вдосконалення свого професійного рівня з використанням наукової та методичної літератури з психологічних та суміжних дисциплін; засвоєння 
власного досвіду та досвіду своїх колег та надання їм допомоги при труднощах.

Незалежність експерта є одним із наріжних каменів. В ï основі лежать об'єктивність, неупередженість та відповідальність судового експертапсихолога. Компонентами незалежності є: незалежність експерта від судовослідчих органів; незалежність від інших учасників кримінального процесу; незалежність від інших експертів-психологів (ситуація, коли думки членів комісії не збігаються одна 3 одною); незалежність від себе (особисті упередження, непрофесійні мотиви). Конфіденційність - експерт не має права розголошувати свідчення, які стали відомі йому у процесі дослідження.

Таким чином, взаємовідносини законності та етики в діяльності експертапсихолога в рамках виробництва експертизи, можна назвати принципом «воронки»: психолог повинен діяти строго в рамках закону, але варіанти його поведінки (часто альтернативні в залежності від ситуації, в якій проводиться експертиза), мають на увазі етичний вибір, що диктується загальною моральною позицією експерта. Ось чому експерт-психолог, зіштовхнувшись у своїй роботі зі складними етичними колізіями повинен пам'ятати про найбільш загальні моральні цінності: справедливість, неупередженість, об'єктивність, відповідальність.

Під час проведення судової експертизи або експертного дослідження 3 метою виконання певного завдання експертами застосовуються відповідні методи дослідження (загальні, загальнонаукові, спеціальні), методики проведення судової експертизи, нормативно-правові акти та нормативні документи (міжнародні, національні та галузеві стандарти, технічні умови, правила, норми, положення, інструкції, рекомендації, переліки, настановчі документи Держспоживстандарту України), а також чинні стандарти УРСР та державні класифікатори, галузеві стандарти та технічні умови СРСР, науковотехнічна, довідкова література, програмні продукти, мережа Інтернет тощо. Вказаний перелік методів не є вичерпним [6].

Етика наукових досліджень - інструментарій, який використовує експертпсихолог при проведенні експертизи, повинен бути апробованим у відповідних науково-дослідних роботах. Крім того, моральною нормою $\epsilon$ неприпустимість застосування таких методів дослідження, які здатні погіршити психічний стан підекспертного.

Тому завданням експерта-психолога $\epsilon$ орієнтація на такі методи, які дозволяють виявляти психологічні особливості 3 урахуванням соціальних умов, забезпечують науковість, об’єктивність та адекватність інтерпретації отриманих даних.

На відміну 3 інших видів доказів, висновок експерта грунтується 3 його розумової діяльності, формує свої висновки 3 урахуванням внутрішнього переконання, що передбачає суб'єктивний чинник. Останній має на увазі наявність певних морально-етичних якостей, властивих людині як особистості, індивіду, і експерту. Наявність даних характеристик багато в чому визначають 
об'єктивність експертного дослідження, що грунтується на спеціальних знаннях, практичних навичках щодо їх застосування у професійній сфері, a також на певному рівні професіоналізму, яким володіє конкретний експерт.

Висновки. Отже, правовий статус судового експерта-психолога під час досудового розслідування кримінального провадження - це сукупність правових елементів які характеризують місце, роль й компетенцію експертапсихолога в юридичному процесі. До правових елементів правового статусу судового експерта-психолога в кримінальному процесі на стадії досудового розслідування відносяться їхні юридичні обов'язки та права, заборонні заходи, коли експерту прямо забороняється вчиняти певні дії, та його юридична відповідальність за неналежне виконання своїх посадових обов'язків, або зловживання ними.

\section{Jimepamypa:}

1. Алікіна Н. В. Зазираючи в душу / Н. В. Алікіна // Укр. юрист. - 2003. - № 10. C. $32-35$.

2. Борисова B.I. Цивільне право України: [підручник]. У 2 т./B.I. Борисова, Л.М. Баранова, І.В. Жилінкова та ін.: за заг. ред. В.І. Борисової, І.В. Спасибо-Фатєєвої, В.Л. Яроцького. - К.:Юрінком Інтер, 2004. - Т.2. - 552c.

3. Бурлака І.В. Зобов'язання з відшкодування шкоди, завданої без вини: [монографія]/ I.В. Бурлака - Х.: Право, 2016. - 200 с.

4. Васильєв В. Окремі питання визначення поняття моральної (немайнової) шкоди. Науковий вісник Ужгородського національного університету. Серія «Право». 2015. Вип. 32. C. 10-15.

5. Ерделевський А.М. Компенсація моральної шкоди. Москва : МАУП, 1996. 240 с.

6. Інструкції з організації проведення та оформлення експертних проваджень у підрозділах Експертної служби Міністерства внутрішніх справ України Наказ Міністерство внутрішніх справ України від 17.07.2017. № 591. 2019. URL: https://zakon.rada.gov.ua/ laws/show/z1024-17/

7. Кримінальний процесуальний кодекс України. Голос України офіційне видання від 19.05.2012. № 90-91.

8. Отраднова О. Компенсація моральної шкоди, заподіяної порушенням цивільноправового договору. Вісник Національної Академії прокуратури України. 2015. № 2. С. 18-23.

9. Порядок ведення Реєстру методик проведення судових експертиз: затверджений наказом Міністерства юстиції України 02.10.2008 N1666/5 / Офіційний сайт Верховної Ради України. - [Електронний ресурс]. - Режим доступу: http://zakon.rada.gov.ua/laws/ show/z0924-08

10. Постанова Пленуму Верховного суду України від 31.03 .1995 № 4 «Про судову практику в справах про відшкодування моральної (немайнової) шкоди» / Офіційний сайт Верховної Ради України. - [Електронний ресурс]. - Режим доступу: http://zakon.rada.gov.ua/ laws/show/v0004700-95

11. Про судову експертизу. Закон України. Голос України офіційне видання від 21.04.1994.

12. Цивільне право України. Академічний курс: [підручник]. У 2 томах/ За заг. ред. Р.О. Стефанчука. - К.: Наукова думка; Прецедент, 2004 - 448 с.

13. Цивільне право України: Академічний курс. Підручник. У двох томах/ За заг. ред. Л.М. Шевченко. - Т.2. Особлива частина. - К.: «Ін Юре», 2003;с. 322.

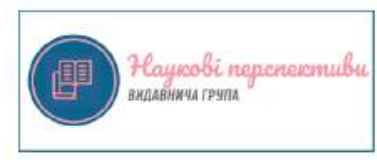




\section{References:}

1. Alikina, N. V. (2003). Zazyrajuchy v dushu [Peering into the soul]. Ukr. jurist - Ukr. lawyer, 10, 32-35 [in Ukrainian].

2. Borysova, V.I., Baranova, L.M., \& Zhylinkova, I.V (Ed.). (2004) Cyviljne pravo Ukrajiny: [pidruchnyk] [Civil law of Ukraine]. (Vols.1-2). Kyiv: Jurinkom Inter [in Ukrainian].

3. Burlaka, I.V. (2016). Zobov'jazannja z vidshkoduvannja shkody, zavdanoji bez vyny [Obligation to compensate for damage caused without fault]. Kharkiv: Pravo [in Ukrainian].

4. Vasyljjev, V. (2015) Okremi pytannja vyznachennja ponjattja moraljnoji (nemajnovoji) shkody. [Some issues of defining the concept of moral (non-pecuniary) damage]. Naukovyj visnyk Uzhghorodsjkogho nacionaljnogho universytetu - Scientific Bulletin of Uzhhorod National University, 32, 10-15 [in Ukrainian].

5. Erdelevsjkyj, A.M. (1996). Kompensacija moraljnoji shkody [Compensation for nonpecuniary damage]. Moskva: MAUP [in Ukrainian].

6. Instrukciji $\mathrm{z}$ orghanizaciji provedennja ta oformlennja ekspertnykh provadzhenj $\mathrm{u}$ pidrozdilakh Ekspertnoji sluzhby Ministerstva vnutrishnikh sprav Ukrajiny Nakaz Ministerstvo vnutrishnikh sprav Ukrajiny vid 17.07.2017. № 591. [Instructions on the organization and conduct of expert proceedings in the divisions of the Expert Service of the Ministry of Internal Affairs of Ukraine Order of the Ministry of Internal Affairs of Ukraine dated 17.07.2017. № 591]. (n.d.). zakon.rada.gov.ua. Retrieved from https://zakon.rada.gov.ua/laws/show/z1024-17/ [in Ukrainian].

7. Kryminaljnyj procesualjnyj kodeks Ukrajiny [Criminal Procedure Code of Ukraine]. (2012, May 19). Gholos Ukrajiny - Voice of Ukraine. 90-91[in Ukrainian].

8. Otradnova, O. (2015). Kompensacija moraljnoji shkody, zapodijanoji porushennjam cyviljno-pravovogho doghovoru [Compensation for non-pecuniary damage caused by breach of a civil contract]. Visnyk Nacionaljnoji Akademiji prokuratury Ukrajiny - Bulletin of the National Academy of the Prosecutor's Office of Ukraine, 2, 18-23 [in Ukrainian].

9. Porjadok vedennja Rejestru metodyk provedennja sudovykh ekspertyz: zatverdzhenyj nakazom Ministerstva justyciji Ukrajiny 02.10.2008 N1666/5 [Procedure for maintaining the Register of methods of forensic examinations: approved by the order of the Ministry of Justice of Ukraine 02.10.2008 N1666 / 5]. (n.d.). zakon.rada.gov.ua. Retrieved from http://zakon.rada.gov.ua/laws/show/z0924-08 [in Ukrainian].

10. Postanova Plenumu Verkhovnogho sudu Ukrajiny vid 31.03.1995 \# 4 «Pro sudovu praktyku v spravakh pro vidshkoduvannja moraljnoji (nemajnovoji) shkody» [Resolution of the Plenum of the Supreme Court of Ukraine of 31.03.1995 № 4 "On judicial practice in cases of compensation for moral (non-pecuniary) damage"]. (n.d.). zakon.rada.gov.ua. Retrieved from http://zakon.rada.gov.ua/laws/show/v0004700-95 [in Ukrainian].

11. Pro sudovu ekspertyzu. Zakon Ukrajiny [About forensic examination. Law of Ukraine]. (1994, April 21). Gholos Ukrajiny- Voice of Ukraine. [in Ukrainian].

12. Stefanchuk, R.O. (Eds.). (2004). Cyviljne pravo Ukrajiny. Akademichnyj kurs. [Civil law of Ukraine. Academic course]. Kyiv: Naukova dumka; Precedent [in Ukrainian].

13. Shevchenko, L.M.(Eds.). (2003). Cyviljne pravo Ukrajiny: Akademichnyj kurs. . [Civil law of Ukraine. Academic course]. (Vols 1-2). Kyiv: In Jure [in Ukrainian]. 